\title{
Competitive Strengthening of BUMdesa in Facing Industrial Revolution 4.0
}

\author{
Herman $^{1}$, Dion Ahmad Armadi $^{2}$ \\ \{herman_fhz@unpak.ac.id ${ }^{1}$,dionachmad@gmail.com $\left.{ }^{2}\right\}$ \\ Fakultas Ekonomi Universitas Pakuan, Bogor - Indonesia ${ }^{12}$
}

\begin{abstract}
, many regulations to improve community welfare and village income does not increase awareness of the village apparatus in the Bogor Regency to establish microfinance institutions and BUMDesa. Moreover, Law No. 6/2014 on the Use of Village Funds has been running for three years, but its use by villages in Bogor Regency is more focused on the physical, but less on community empowerment. The purpose of the management assistance activities of (BumDesa) get training and mentoring aspects of business and governance that ultimately BUMDesa has professional organizational capabilities and can have competitiveness in the face of the industrial revolution 4.0. The method used to determine the model and training needs and assistance is first performed is to use a SWOT analysis. The analysis shows that BUMDesa managers need assistance in the form of training and education, the right model of assistance is mentoring through BUMDesa Clinics and Schools. Pakuan University has assisted through BUMDesa Clinics and Schools that have been established and as a result several BUMDesa have had good governance.
\end{abstract}

Keywords: BUMDesa, SWOT Analysis, Clinics and Schools

\section{Introduction}

The development of the economic base in rural areas has long been carried out by the government through various programs. But these efforts have not produced satisfying results as desired together. One of the most dominant factors is that government intervention is too large, the result is that it inhibits the creativity and innovation of rural communities in managing and running the economic engine in the countryside. The system and mechanism of economic institutions in rural areas are not running effectively and have implications for dependence on government assistance, thus killing the spirit of independence. Based on this assumption, the existence of the village should receive serious attention from the central government with the birth of policies related to economic empowerment carried out by collecting and institutionalizing economic activities of the community. Therefore, the government applies a new approach that is expected to be able to stimulate and 
move the wheels of the rural economy through the establishment of an economic institution that is fully managed by the village community, namely the Village Owned Enterprise (BUMDesa) as one of the mainstay programs in increasing the independence of the village economy.

Although there are many regulations related to efforts to improve community welfare and village income, it turns out that awareness of the village apparatus, especially in Bogor Regency, to establish microfinance institutions and BUMDesa villages is still lacking. In addition, village officials still do not understand how to implement the business organization management system mechanism. This is the obstacle. Even though BUM Desa is a pillar of the village economy. In the regulation, it is stated that one village must have a BUMDesa, whose business type is adjusted to the potential, resources and services of basic community needs.

Village-Owned Enterprises (BUMDesa) are village businesses formed / established by village governments whose capital ownership and management are carried out by village and community governments [1]. The more comprehensive definition of village-owned enterprises (BUMDesa) is contained in [2] in which Village-Owned Enterprises (BUMDesa) are business entities which all or most of their capital are owned by villages through direct participation from village assets that are separated to manage assets, services, and other businesses for the maximum welfare of the community village. Village-Owned Enterprises (BUMDesa) can also be defined as village business institutions that are managed by the community and village government in an effort to strengthen the village economy and are formed based on the needs and potential of the village. Village potential in this case is a benchmark for making village businesses. According to [3], Village Business is a type of business in the form of village economic services such as, service businesses, distribution of nine staples, trade in agricultural products, as well as industry and folk crafts. As an institution for economic development of rural communities, BUMDesa has several goals. The purpose of establishing BUMDesa is to increase the village's original income in order to improve the ability of the Village Government in governance and development and community services, develop economic potential in rural areas to encourage the development and economic capacity of the rural community as a whole, and create employment.

The Bogor Regency Government stated that out of 416 new villages of 282 that have Village-Owned Enterprises (BUMDesa), there are still 134 villages that do not yet have BUMDesa. Of the 282 BUMDesa, these can be categorized as follows: 
Table 1. BUMDesa data in Bogor Regency

\begin{tabular}{ccccccccr}
\hline Year & $\begin{array}{c}\text { Total of } \\
\text { Village }\end{array}$ & $\begin{array}{c}\text { BUM } \\
\text { Desa }\end{array}$ & Active & Non & \multicolumn{4}{c}{ Category } \\
& Active & Elementary & Develop & Up & Independent \\
\hline 2016 & 416 & 201 & 98 & 103 & 190 & 10 & 1 & \\
2017 & 416 & 249 & 127 & 122 & 238 & 10 & 1 & \\
2018 & 416 & 282 & 161 & 121 & 148 & 11 & 2 & \\
Sources : DPMD Kabupatem Bogor (2018) & \multicolumn{6}{c}{}
\end{tabular}

The existence of BUMDesa is very important so that the economy in the village can develop and be independent. Although there have been many regulations related to efforts to improve community welfare and village income, it turns out that awareness of the village apparatus in Bogor Regency to establish microfinance institutions and BUMDesa is still lacking. Various central and regional government efforts aimed at making the economy develop and be independent but have not yet been maximized. Moreover, in Law No. $6 / 2014$ on Village Fund Users it has been running for three years, but its use by villages in Bogor Regency is more focused on physical, but less on community empowerment. BUM Desa in Bogor Regency is like two sides of a coin. On one hand saving potential and hope for people's lives through optimizing the potential of natural and human resources, on the other hand BUM Desa has complicated problems. BUMDesa in Bogor Regency is indeed not maximally managed professionally, so it is very vulnerable to horizontal conflicts. Some of the problems encountered in the Bogor Regency BUMDesa include:

1. Business Aspects, consisting of:
a. Production
b. Marketing
c. Business development

2. Governance aspects, consisting of:
a. Administration
b. Organization
c. Finance

From some of these problems it can be concluded that the governance system of the BUMDesa management organization is still lacking, this is due to the lack of BUMDesa administrators getting education and training. Therefore there is a need for assistance to be done by academics. 


\section{Research Methods}

The first method of assisting in developing village-owned enterprises is identified using a SWOT analysis. SWOT analysis is a useful technique for understanding organizational Strengths and Weaknesses, and for identifying both Opportunities that are open to organizations and Threats faced by organizations. The aim of this analysis is to find new opportunities, manage and reduce organizational threats. In a business context, SWOT Analysis helps businesses manage sustainable market niches of companies. In a personal context it is used to help someone develop a career by utilizing the best advantages of talents, abilities, and opportunities. In the context of BUMDesa development or management, SWOT analysis and SWOT matrix are used to formulate the BUMDesa strategic plan.

From the results of identification using the SWOT matrix then the appropriate assistance method is then determined in the form of initial diagnosis as follows:

1. Quadrant 1

This condition is experienced by villages that have not yet established BUMDesa

2. Quadrant 2

This condition is experienced by villages that have established BUMDesa but have not made Village Capital Participation

3. Quadrant 3

This condition is experienced by villages that have established BUMDesa and have made Village Capital Participation, but have not yet circulated businesses

4. Quadrant 4

5. This condition is experienced by villages that have established BUMDesa and have already participated in Village Capital Participation, and have carried out business circulation, but how do they continue.

At this time, obedience of village officials in complying with policies regarding the establishment of BUMDesa is still not optimal, the many potentials of villages that have not yet been developed into business feasibility, can be seen as educational facilities for administrators and managers of BUM Desa. Partnership cooperation, meeting forums and communication facilities do not yet exist. Does not have a wide network of marketing, production and bureaucratic networks. There is no container for solving business problems. BUMDesa management performance has not been evaluated. There is no assessment in risk management. 


\section{Results and Discussion}

The aim of this research is for the BUMDesa management to have a good organizational governance system consisting of business aspects and financial administration aspects. It is expected that the existence of research on village-owned enterprises in Bogor Regency will be able to be useful in driving the dynamics of the village economy and as an agent for regional development as well as driving the creation of small and medium business units.

Based on the results of the analysis of the methodology carried out the following things are carried out:

1. Accelerating the development of BUMDesa

The acceleration of BUMDesa development for quadrant 1 and quadrant 2 through through the identification of potential and problems for institutional development, business and development of BUMDesa Human Resources. This is done in the form of training and assistance in preparing business feasibility analysis, managing human resource needs analysis, marketing analysis and financial statement analysis. All activities are carried out by the lecturer and accompanied by students.

2. Establishment of BUMDesa Business School

The establishment of the BUMDesa Business School Pakuan University is a program that seeks to provide a different and comprehensive model of training and mentoring. BUMDesa Business School Pakuan University offers BUMDesa training concepts based on problems that occur in the field. By combining several methods such as lectures, discussions, Focus Group Discussion (FGD), practice, field trips, and application usage. In the field of assistance, the BUMDesa Business School of Pakuan University divides the BUMDesa mentoring model into 4 different levels according to the quadrant, namely the level of building, growing, developing, and strengthening. As a way of looking at the different contexts and content in each village, these 4 levels are an effort of the BUMDesa Business School of Pakuan University to understand and formulate a mentoring model that is right on target and meets the needs of BUMDesa.

3. Building Partnership Collaboration

Article 18 of Permendesa Number 4 of 2015 indicates that BUMDesa can collaborate with various businesses. Article 18 paragraph (1) reads:

(1) Village capital investment as referred to in Article 17 paragraph (2) letter a consists of: 
a. grants from the private sector, social and economic institutions and / or donor agencies that are channeled through the Village APB mechanism;

b. assistance from the Government, Provincial Governments, and Regency / City Governments distributed through the Village APB mechanism;

c. business cooperation from the private sector, social and economic institutions and / or donor agencies that are ensured as village collective wealth and channeled through the Village APB mechanism;

d. Village Assets submitted to the Village APB are in accordance with statutory provisions concerning Village Assets.

Part c of article 18 clearly shows that BUMDesa can work together with the private sector and other social economic institutions. BUMDesa collaboration with the private sector, such as that carried out by BUMDesa Bogor Regency with Pakuan University in terms of management and financial consultations.

Real action in the context of strengthening the competitiveness of village-owned enterprises in the face of the industrial revolution 4.0 through enhancing the capacity of 30 Bum village employees in Bogor district is carried out through the following matters:

1. Quadrant 1 (This condition is experienced by villages that have not yet established BUMDesa), Pakuan University provides assistance and consultation with the aim of:

a. So that the village must establish BUMDesa

b. In order for the Village to appoint BUMDesa administrators who are not part of the village government and make the BUMDesa organizational structure.

c. BUMDesa Managers are trained by experts who are experts in accordance with their competencies.

2. Quadrant 2 (This condition is experienced by villages that have established BUMDesa but have not yet participated in Village Capital Participation), Pakuan University provides assistance in the form of training with the aim of:

a. So that the Village Government encourages BUMDesa Management to benchmark BUMDesa that has developed and advanced and visits business exhibitions.

b. In order for the BUMDesa Management to submit a Business Plan Proposal to the Village Government so that the Village Government wants to make Village Capital Participation. 
c. So that BUMDesa Managers are trained and accompanied by experts who are experts in accordance with their competencies.

3. Quadrant 3 (This condition is experienced by villages that have established BUMDesa and have made Village Capital Participation, but have not yet circulated a business), Pakuan University provides assistance with the aim of:

a. The Village Government encourages BUMDesa Management to benchmark BUMDesa that has been developed and advanced and visits business exhibitions.

b. BUMDesa Managers continue to be trained and accompanied by experts who are experts in accordance with their competencies.

c. BUMDesa Management is included in BUMDesa Business School

d. BUMDesa Management actively builds Partnership Collaboration

e. The BUMDesa management is active in the regular BUM One Business Management Meeting.

f. BUMDesa Managers are active in the regular BUMDesa Forum.

g. BUMDesa management is active in BUMDesa Clinic

$\mathrm{h}$. BUMDesa Management is active in the BUMDesa Coordination Meeting periodically

4. Quadrant 4 (This condition is experienced by villages that have established BUMDesa and have made Village Capital Participation, and have carried out business circulation, but how is its sustainability), Pakuan University provides assistance and training with the aim of:

a. So that the Village Government encourages BUMDesa Management to benchmark BUMDesa that has developed and advanced and visits business exhibitions.

b. So that BUMDesa Managers continue to be trained and accompanied by experts who are experts in accordance with their competencies.

c. In order for BUMDesa Management to be included in BUMDesa Business School

d. So that BUMDesa Managers actively develop Partnership Collaboration

e. So that BUMDesa Managers are active in periodic BUMDesa Business Meeting

f. So that BUMDesa Managers are active in the BUMDesa Forum on a regular basis

g. So that BUMDesa Managers are active in BUMDesa Clinics

h. So that BUMDesa Managers are active in the BUMDesa

Coordination Meeting periodically 


\section{Conclusion}

The research of BUM Desa in Bogor Regency first performed an analysis using SWOT analysis, SWOT analysis is a useful technique for understanding organizational Strengths and Weaknesses, and for identifying both Opportunities that are open to organizations and Threats. faced by the organization. Basically this analysis seeks to find new opportunities, manage and reduce organizational threats. Based on the results of the analysis, assistance and education must be provided in the form of assistance. Related to training and mentoring for Village Bum administrators in 30 Village Bum in Bogor Regency, this is what Pakuan University has done, namely establishing the BUMDesa Clinic and School which is a vehicle for BUMDesa administrators in Bogor Regency in order to increase capacity and competence in order to strengthen BUMDesa in the face of BUMDesa the industrial revolution era 4.0 


\section{References}

[1] Wiwoho, Jamal dan Munawar Kholil. (2012). "Pengelolaan dan Pembentukan Badan Usaha Milik Desa”. Makalah Review terhadap Rancangan Peraturan Daerah Kabupaten Boyolali tentang Pedoman Pembentukan dan Pengelolaan Badan Usaha Milik Desa.

[2] Undang-Undang Nomor 6 Tahun 2014 Tentang Desa, Lembaran Negara Republik Indonesia Tahun 2014 Nomor 7, Tambahan Lembaran Negara Nomor 5495.

[3] Peraturan Menteri dalam Negeri Nomor 39 tahun 2010 tentang Badan Usaha Milik Desa 